\title{
The Chennai Water Crisis: Insufficient rainwater or suboptimal harnessing of runoff?
}

\author{
Sumant Nigam*, Alfredo Ruiz-Barradas and Agniv Sengupta
}

Chennai experienced acute water shortage during 2019 summer, and four years prior, an earlywinter deluge. Analysis of 116 years (1901-2016) of rainfall in Chennai Sub-basin shows a weak climate change signal: Winter monsoon rainfall, has slightly increased, especially in December. The much larger Cauvery basin to the south also exhibits a nondescript climate change signal in winter rainfall. Late summer (September) rainfall in the Cauvery Basin has, however, precipitously declined in recent years (1987-2016). We show that this decline, as well as the mid-20th century increase, are attributable to natural multidecadal climate variability (Atlantic Multidecadal Oscillation) - cautioning against cavalier attributions of recent-period trends and the Chennai Water Crisis to climate change. Analysis of runoff - the rainwater leftover after its hydrologic and atmospheric processing - shows that harnessing even half of the winter monsoon runoff in the Chennai Sub-basin can satiate the city's water demand for about seven months; and without needing new reservoir facilities. The present analysis suggests that Chennai's water woes arise not from insufficient rainwater, but from the suboptimal harnessing of related runoff.

Keywords: Climate change, monsoon rainfall, multidecadal variability, river basin, runoff.

THE Coromandel Coast - long defined, geographically, as the coastal plains of southeastern Peninsular India backed by the Eastern Ghats to the west and the Bay of Bengal to the east, and bounded by the Krishna and Cauvery river deltas to the north and south respectively - could have as well been defined, climatologically, as the coastal region of eastern Peninsular India receiving peak rainfall in October and November, i.e., during the northeast (NE) winter monsoon. This, unlike the rest of the Indian subcontinent, including the Malabar Coast-Coromandel's counterpart on the west coast, abutted by Western Ghats - where the southwest (SW) summer monsoon rules the seasonal distribution of rainfall. Chennai, a bustling coastal metropolis of more than 10 million people, lies in the middle section of the Coromandel.

Although Coromandel Coast receives peak rainfall in October and November, its summer months are far from dry. The region also includes the lower courses of several east-flowing rivers whose headwaters in the Western Ghats and Deccan Plateau (i.e. summer monsoon-exposed regions) generate resiliency to the vagaries of the monsoon; except when summer and winter monsoon

Sumant Nigam, Alfredo Ruiz-Barradas and Agniv Sengupta are in the Department of Atmospheric and Oceanic Science, University of Maryland College Park, USA; Sumant Nigam was a Fulbright-Nehru Fellow at the Indian Institute of Technology, Mandi 175 001, India during 2020; Agniv Sengupta is currently at the Jet Propulsion Laboratory, California Institute of Technology, Pasadena, USA.

*For correspondence. (e-mail: nigam@umd.edu) variations are similarly phased - the case, perhaps, in 2019.

Lately, Chennai has witnessed both floods and severe water scarcity. The heavy rainfall in late November-early December of 2015 led to a deluge ${ }^{1}$ and significant loss of life and property ${ }^{2,3}$. The severe water shortage in the early summer of 2019 - the Chennai Water Crisis - originated in the large winter rainfall deficit in 2018 and its subsequent compounding by the late arrival of summer rains the following year ${ }^{4}$. Although impressive, such hydroclimate variability is not uncommon in the Coromandel as the NE monsoon is more variable than the SW monsoon due both to its shorter duration (leading to greater impacts of onset and retreat variations) and greater exposure to intraseasonal variabilities, such as Madden-Julian Oscillation, which is more robust in winter with impressive footprints over Peninsular India ${ }^{5}$. The high ratio of the interannual standard deviation to climatology in winter rainfall attests to the larger interannual variability of the NE monsoon ${ }^{6-8}$.

Chennai is not located on the banks of a major river and, as such, dependent on rainfed reservoirs and, lately, on groundwater for its water supply ${ }^{9}$, and on wetlands for natural drainage. The four rainfed reservoirs/lakes (Poondi, Cholavaram, Redhills and Chembarambakkam) have a combined 15-yr (2005-2019) average-fill of $\sim 175 \times 10^{6} \mathrm{~m}^{3}$ in December and January ${ }^{10}$. Storage was down to $\sim 11 \times 10^{6} \mathrm{~m}^{3}(\sim 17 \%$ average-fill $)$ in December 2018-January 2019 following the weak 2018 winter 
monsoon, and precipitously down to $\sim 0.5 \times 10^{6} \mathrm{~m}^{3}(<1 \%$ average-fill) in July 2019 in the peak phase of the Chennai Water Crisis, which followed the delayed onset of the SW monsoon. The reservoirs are primed by summer monsoon and filled during winter monsoon, attaining peak levels in December and January, with fill levels dependent on fluctuant monsoons. El Niño - the warm phase of the El Niño Southern Oscillation - which suppresses summer rainfall over most of the Indian subcontinent ${ }^{11,12}$ - increases winter monsoon rainfall in the Coromandel, especially in November ${ }^{7}$.

Chennai's reservoir-based water supply was recently augmented by water from the Krishna and Cauvery rivers. Water from the Krishna (in the north) comes via Telugu Ganga Canal - a $405 \mathrm{~km}$ canal linking Srisailam reservoir in Andhra Pradesh to the Poondi reservoir. Krishna water arrivals began in 2004 , but the delivery has been unsteady because of multi-state claims on river water, and because of farmer resistance and diversions along the canal ${ }^{13}$, leading to significantly smaller receipts than the annually permitted July-October uptake $\left(\sim 425 \times 10^{6} \mathrm{~m}^{3}\right)$; for example, only a tenth was received by early 2019 (ref. 14). Water from the Cauvery (in the south) was tapped via Veeranam Lake, located $225 \mathrm{~km}$ south of Chennai and just upstream of the Cauvery Delta. Piped water delivery from Veeranam Lake also commenced in 2004 but has been erratic, being dependent on the release of surplus Cauvery water through the Mettur Dam; for example, in April 2019, $0.17 \times 10^{6} \mathrm{~m}^{3}$ of water was supplied each day to Chennai ${ }^{15}$. Two desalination plants along the coast at Minjur and Nemmeli, operative since 2010 and 2013 respectively, provide another $\sim 0.2 \times 10^{6} \mathrm{~m}^{3}$ of water each day to Chennai ${ }^{16}$. A growing movement to harvest rainwater also helps via groundwater replenishment ${ }^{17}$.

The Chennai Water Crisis came to a head during midsummer of 2019, drawing wide media attention ${ }^{4,9,18,19}$ and spurring causal analyses. Increased demand and loss of precious wetlands from urban sprawl and auto industry growth, upstream deforestation, water resources mismanagement, and droughts and climate change ${ }^{9}$ have all been implicated.

The present study targets the hydroclimate of the Coromandel region. Regional rainfall is analysed to identify both long-term (i.e. century-long) and short-term (over recent decades) trends. The long-term trends are indicative of climate change, while short-term trends of multidecadal climate variability. Rainfall trends are analysed for the Chennai Sub-basin and the neighbouring Cauvery basin. Subsequent analysis of runoff - the rainwater leftover after hydrologic and atmospheric processing of rainfall - completes the study providing insights on the surface-water potential of the region. The analysis provides the hydrometeorological context for Chennai's water woes, including whether they arise from insufficient rainwater or suboptimal harnessing of runoff.

\section{Data and methods}

\section{Physiography data}

Topography and bathymetry were obtained from the National Oceanic and Atmospheric Administration (NOAA's) National Oceanographic Data Center's ETOPO1 Global Relief Model $^{20}$, a 1 arc-min resolution relief model of the Earth's surface. River shapefiles were obtained from the Global Runoff Data Centre's Major River Basins of the World ${ }^{21}$ and the AQUAMAPS rivers of the world ${ }^{22}$, while watershed boundaries were from the World Wildlife Fund's Conservation Science Program's HydroSHEDS 30 arc-sec resolution georeferenced data ${ }^{23}$. The basins were discretized using MeteoInfo software ${ }^{24}$, whose output is compatible with the Grid Analysis and Display System (GrADS) ${ }^{25}$, a data processing and visualization program used extensively in this analysis.

Figure 1 shows the physio-geography of southern Peninsular India. Cauvery, the largest river in the region,

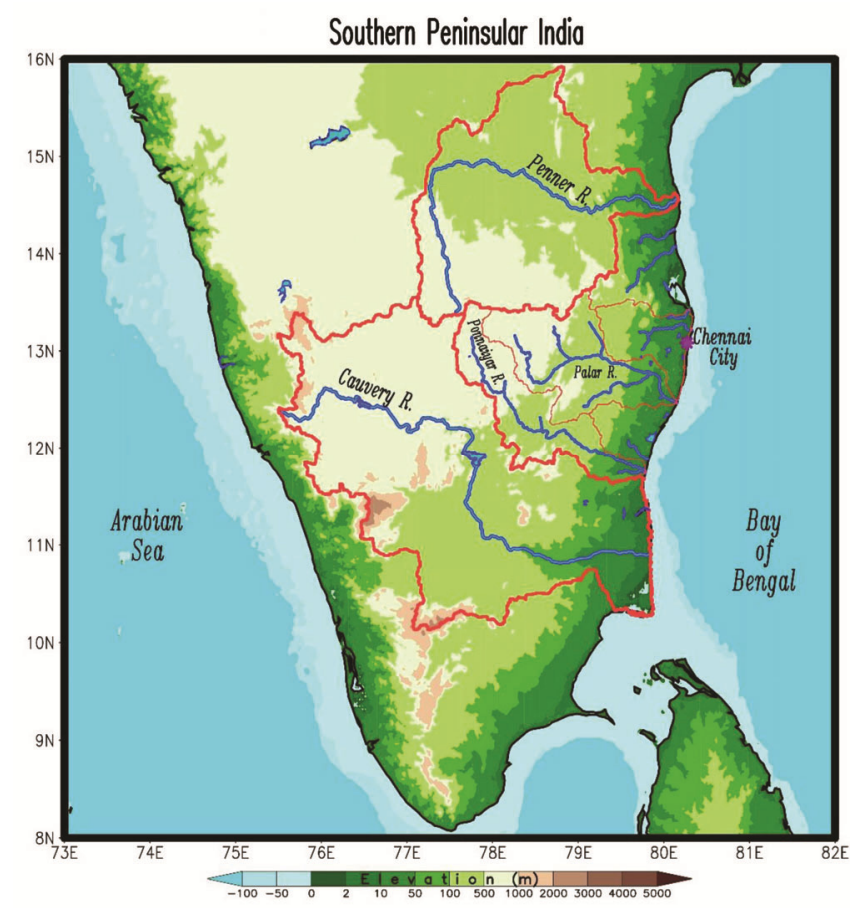

Figure 1. River basins around Chennai. Basins of the east-flowing rivers are superposed on the elevation map of southern Peninsular India. Chennai city is marked by a purple asterisk, basins are outlined in red, and rivers and lakes in blue. Brown/green shading denotes elevation $(\mathrm{m})$ and blue shading denotes bathymetry; elevations less than $10 \mathrm{~m}$ are deltas and depths less than $50 \mathrm{~m}$ are coastal shelves. The Cauvery and Penner river basins effectively cordon off Chennai and its neighbouring region (referred here as the Eastern Basin). Within the Eastern Basin are the Palar and Ponnaiyar river basins (thin red lines) as well as the coastal sub-basins of Varahanadhi River (east-southeast of Ponnaiyar and Palar basins) and Naidupet River (southeast of Penner basin), and the Chennai Sub-basin (between Palar and Naidupet basins) in which Chennai is located; all marked. The Chennai Sub-basin also includes local rivers: Kosasthalaiyar to the north, Adyar to the south, and the Cooum between them; these are not marked. Basin sizes are noted in Table 1. 
has its headwaters in the Western Ghats, while Ponnaiyar, Palar and Penner rivers have their source in the Deccan Plateau.

\section{Precipitation and runoff}

Rain gauge-based monthly precipitation on a $0.25^{\circ}$ continental grid for the period 1901-2016 was from the German Meteorological Service's (DWD) Global Precipitation Climatology Centre (GPCC, ver. 8) ${ }^{26}$. Rain gaugebased data from India Meteorological Department (IMD, ver. 4$)^{27}$ was also used in select inter-comparisons. This daily data (1901-present) is based on $\sim 7800$ stations and gridded on a $0.25^{\circ}$-grid.

Runoff was obtained from the Global Runoff (GRUN) reconstruction dataset (ver. 1) ${ }^{28}$, where in situ streamflow observations (from Global Streamflow Indices and Metadata archive) train a machine learning algorithm that predicts monthly runoff rates based on antecedent precipitation and temperature (from Global Soil Wetness Project Phase-3 meteorological forcing dataset). The ensemble mean of 50 GRUN reconstructions obtained from training with different data subsets has been used here; monthly runoff is available on a $0.5^{\circ}$ grid during 1902-2014 from https://figshare.com/articles/GRUN_ Global_Runoff_Reconstruction/9228176.

\section{Basin rainwater receipts}

Basin rainwater receipts were obtained by multiplying rainfall on the $0.25^{\circ}$ continental grid by the grid-cell area, followed by integration over the discretized basin using the GrADS asum function, which implicitly accounts for the variation of the grid-cell area with latitude.

\section{Multidecadal climate variability}

The attribution of recent period rainfall trends requires factoring for multidecadal climate variability. Atlantic Multidecadal Oscillation (AMO) and Pacific Decadal Oscillation are two major modes of sea surface temperature (SST) variability whose influence extends to the Indian subcontinent; their influence on summer monsoon rainfall is well documented ${ }^{29-31}$, but not the influence on winter monsoon. The AMO was tracked using the NOAA-AMO index ${ }^{32}$, defined as the linearly detrended, area-averaged SST anomaly in the North Atlantic $\left(75^{\circ}\right.$ $5^{\circ} \mathrm{W}$, EQ- $\left.60^{\circ} \mathrm{N}\right)$. The index was smoothed with the LOESS filter using a $15 \%$ span window (LOESS-15) ${ }^{33}$; the span is $\sim 17$ years for the 1901-2016 record, which is approximately one-fourth of AMO's estimated period $(50-70 \text { years })^{34-36}$. By suppressing the subseasonal-tointerannual-to-decadal variabilities, the LOESS-15 filter highlights the multidecadal fluctuations in the 1901-2016 record.

\section{Rainfall analysis}

\section{Spatiotemporal distribution of rainfall}

Harmonic analysis of climatological monthly rainfall yields the annual mean (contoured) and annually varying (arrows) components of rainfall ${ }^{7,37}$ (Figure 2, top). Annual-mean rainfall is notably large $(7-8 \mathrm{~mm} /$ day $)$ in the northeast and along the west coast (Konkan and Malabar), but modest (2-4 mm/day) over southeastern Peninsular India. The arrows succinctly portray the seasonality (i.e. monsoonal nature) of rainfall, with July being the peak rainfall month across most of the subcontinent, reflecting the pervasive influence of the SW summer monsoon. The red-arrow region in Figure 2 indicates rainfall peaks in October-December. This early-winter rainfall is from the NE monsoon which brings moisture from the Bay of Bengal via low-level northeasterlies? The red-arrow region effectively outlines the Coromandel Coast, as noted in the introduction. The winter monsoon also prevails over Sri Lanka, except for its southwest corner.

The rainfall distribution in the pre-summer monsoon, summer monsoon and winter monsoon periods is overlaid on the river basins of Peninsular India (Figure 2, lower panels). The Coromandel receives rainfall from the winter monsoon (6-8 $\mathrm{mm} /$ day) and from the summer monsoon (2-4 mm/day). The Chennai Sub-basin gets twice as much rainfall in early winter as summer. The premonsoon period (January-May) is the dry period over the Eastern Basin, including the Chennai Sub-basin. The Cauvery basin gets more rainfall during the winter monsoon, but the Penner basin receives more during the summer monsoon.

\section{Climatological basin rainfall and rainwater receipts}

Figure 3 shows the monthly variation of average rainfall and rainwater volume received in each basin. Table 1 notes the period accumulations. Basin-averaged rainfall generally increases from late spring to early winter, with only the Cauvery basin exhibiting a secondary peak in July. Rainfall in the Penner basin - the northernmost peaks in September, i.e. at the tail end of the SW monsoon. Peak rainfall in the other basins occurs during the winter monsoon: in October in the Cauvery and Eastern basins, and in November in the Chennai Sub-basin. Basin rainfall is largest in the Chennai Sub-basin, as it is most exposed to the coastally focused NE winter monsoon.

The volume of rainwater received in each basinthe basin rainwater receipts-depends both on 

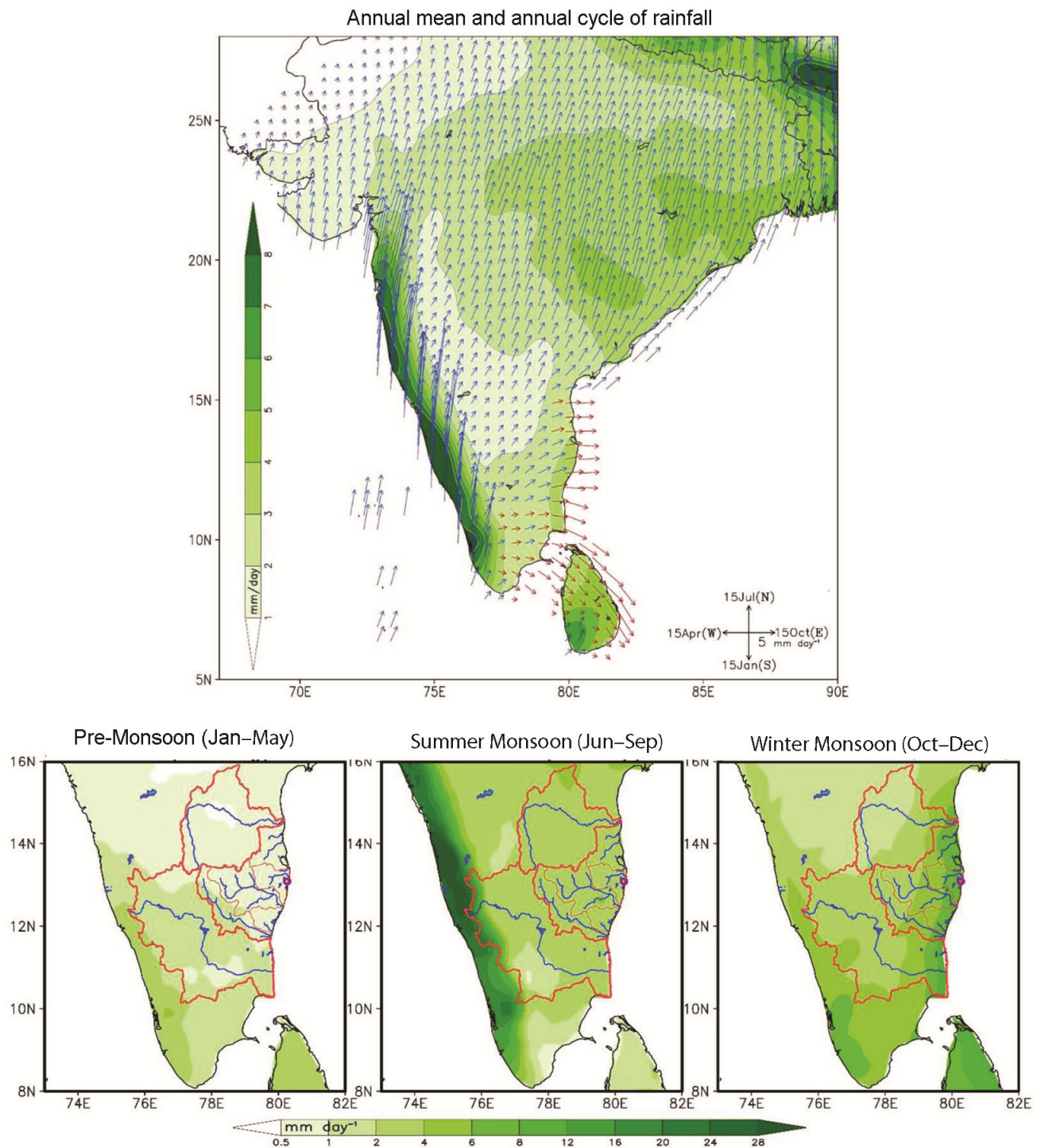

Figure 2. Climatological rainfall over the Indian subcontinent. (Upper panel) Arrows represent the annual cycle (first harmonic) and contours the annual mean ( $\mathrm{mm} / \mathrm{day})$ of rainfall. The arrow scale and phase convention are shown in the lower-right corner; arrows pointing north indicate July as the peak rainfall month, and so on. Arrows in red mark regions receiving peak rainfall during October-December, i.e. during the northeast winter monsoon. Arrows are plotted when their amplitude is $\geq 0.75 \mathrm{~mm} /$ day. Contouring and shading interval as in the colour bar on the left. (Lower panel) Climatological rainfall over southern Peninsular India, with blue and red lines denoting the main rivers and their basin boundaries, following Figure 1. The 1901-2016 GPCC rainfall climatology is analysed. The fields are shown after four applications of smth9 in GrADS.

basin-averaged rainfall and basin area. Cauvery, with the largest area $\left(93,814 \mathrm{~km}^{2}\right)$, is the clear frontrunner in all calendar months (Figure 3, lower panel). In early summer, its rainwater receipts are more than twice as large as the Penner and Eastern basins, and many times larger than the Chennai Sub-basin, which because of its small size $\left(6,773 \mathrm{~km}^{2}\right)$ ranks the lowest even in early winter when it has the largest rainfall. Other notable features include (also from Table 1):

- Cauvery basin is unique because of exposure to both monsoons.
- Large basins with deep extensions into the interior (e.g. Cauvery, Penner, Palar and Ponnaiyar) receive more rainwater during summer monsoon.

- Smaller, coastally confined basins (e.g. Naidupet, Chennai and Varahanadhi), on the other hand, receive significantly more rainwater during winter monsoon. For example, Chennai Sub-basin receives $\sim 38 \%$ of its annual water from the summer monsoon, but as much as $\sim 51 \%$ from the winter monsoon.

The amount of rainwater received in the Chennai Sub-basin is compared with the average-fill volume of 


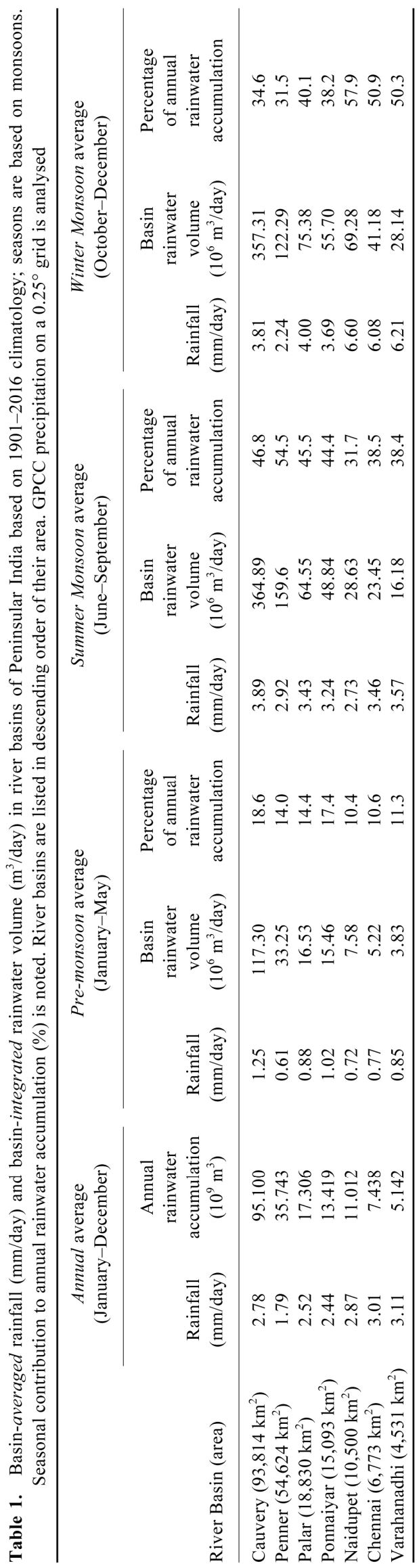


Chennai's four rainfed reservoirs, annual recruitment of the Cauvery and Krishna waters, and, above all, Chennai city's potential water needs and current supply in the runoff analysis section.

\section{Interannual variability and trends in basin rainfall}

To provide context for the Chennai Water Crisis, interannual variability and long-term trends in basin rainfall were analysed (Figure 4). While rainfall is key, its disposal-soil moisture recharge, evapotranspiration, infiltration, and runoff - can also modulate regional hydroclimate episodes. The large rainfall $(7-8 \mathrm{~mm} /$ day) in October-November in the Chennai Sub-basin (top panel) and its impressive year-to-year variability (SD of 4-6 mm/day is two-thirds of climatology) stand out; the larger variability of winter monsoon was noted earlier. Such large variations, if superposed, on long-term trends, can generate extreme episodes. (Attribution of the 2015 early-winter Chennai deluge however requires a more elaborate analysis framework, one extending beyond monthly timescales to the weekly/daily ones.)

The centennial rainfall trend in the Chennai Sub-basin (thick red line) is near-zero, but positive during SeptemberNovember; notably positive in December $(+1.3 \mathrm{~mm} /$ day/ century, vis-à-vis climatology of $\sim 3.3 \mathrm{~mm} /$ day); and negative in January $(-1.1 \mathrm{~mm} /$ day/century, against climato$\operatorname{logy}$ of $\sim 0.8 \mathrm{~mm} /$ day). As centennial trends - reflecting more of the climate change signal - are positive in each month but January, global climate change cannot be implicated in the Chennai Water Crisis, at least from the
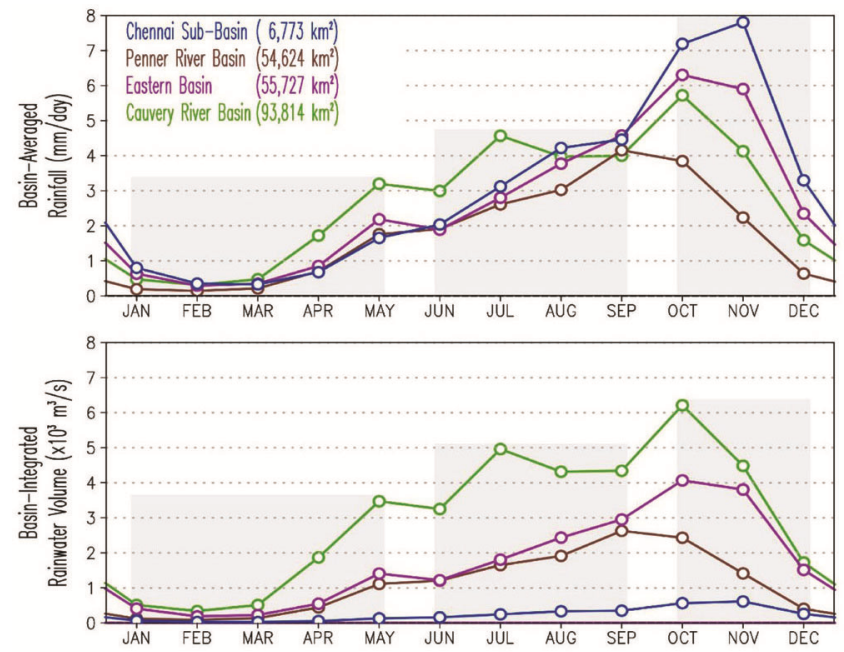

Figure 3. Monthly rainfall and rainwater volume in river basins of southern Peninsular India. Monthly basin-averaged rainfall (mm/day; top), and basin-integrated rainwater volume $\left(\mathrm{m}^{3} / \mathrm{s}\right.$; bottom) for the Chennai Sub-basin, and the Penner, Eastern, and Cauvery basins (cf. Figure 2). GPCCv8 $0.25^{\circ}$ resolution data are analysed with climatology based on the 1901-2016 period. Grey shading marks the pre-summer monsoon, summer monsoon and winter monsoon periods. Basin areas are noted in the legend and also in Table 1. perspective of rainfall, the controlling element of atmospheric and terrestrial water cycles. The rainfall decline in January - significant, as it is a dry month $(<1 \mathrm{~mm} /$ day $)$ to begin with - cannot be overlooked, but its hydroclimate impact is likely ameliorated as it follows December, a positive-trend month. Climate change, on the other hand, can perhaps be implicated in December being more wet in the Chennai Sub-basin, but not necessarily in the generation of intense weekly episodes such as the earlywinter deluge in 2015.

The recent 30-yr trends are larger than centennial ones from exposure to multidecadal climate variability (50-70yr timescale) and, possibly, accelerated climate change ${ }^{38}$; these trends also exhibit notably less month-to-month coherence than their centennial counterparts. Recent trends in the Chennai sub-basin are strongly positive in October and December $(+3.76 \mathrm{~mm} /$ day/century) and negative in November. The December trend is the strongest of all months.

Centennial rainfall trends over the Cauvery basin are near-zero but for July, August and January when they are negative; e.g. the trend is $-0.6 \mathrm{~mm} /$ day/century in July when climatological rainfall is $\sim 4.5 \mathrm{~mm} /$ day, indicating a
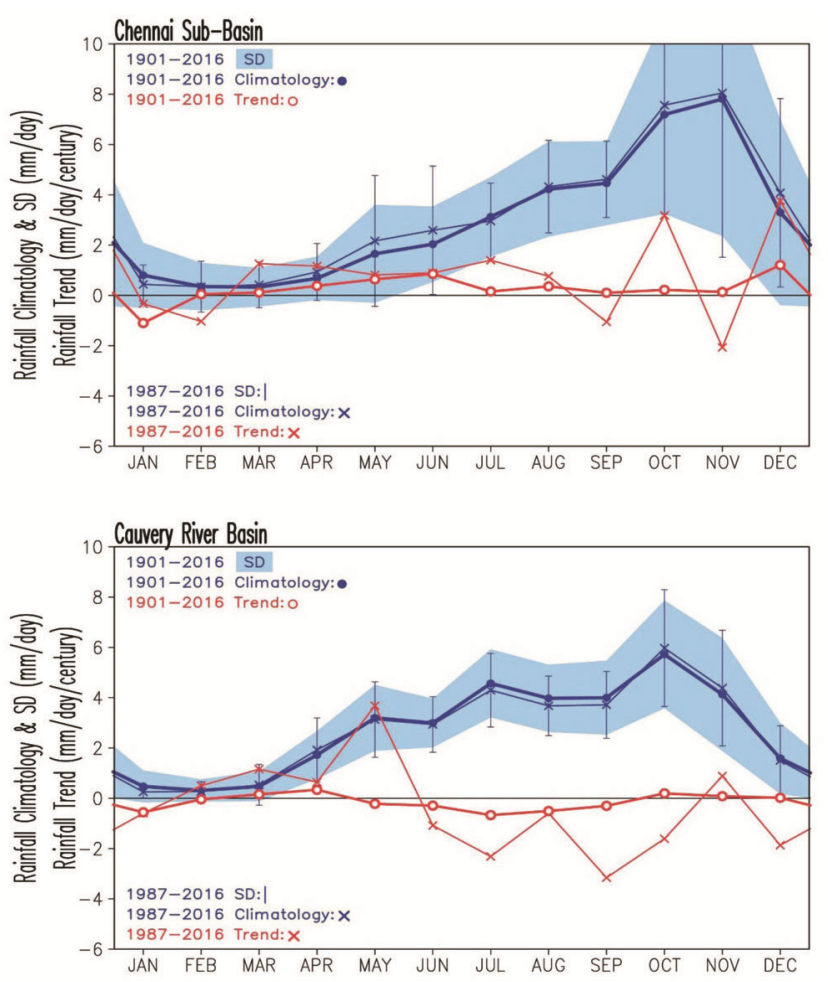

Figure 4. Climatology, variability, and trends in basin rainfall. Climatology ( $\mathrm{mm} /$ day), standard deviation $(\mathrm{SD}, \mathrm{mm} /$ day) and linear trend $(\mathrm{mm} /$ day/century) in basin-averaged rainfall are shown in a centurylong (1901-2016; thick lines) and a recent 30-yr period (1987-2016; thin lines), as indicated in the legends. (Top) Chennai Sub-basin and (bottom) Cauvery river basin. The \pm 1 SD spread around climatological values is indicated using the shaded ribbon in the 116 -yr period and solid vertical lines in the recent period. 

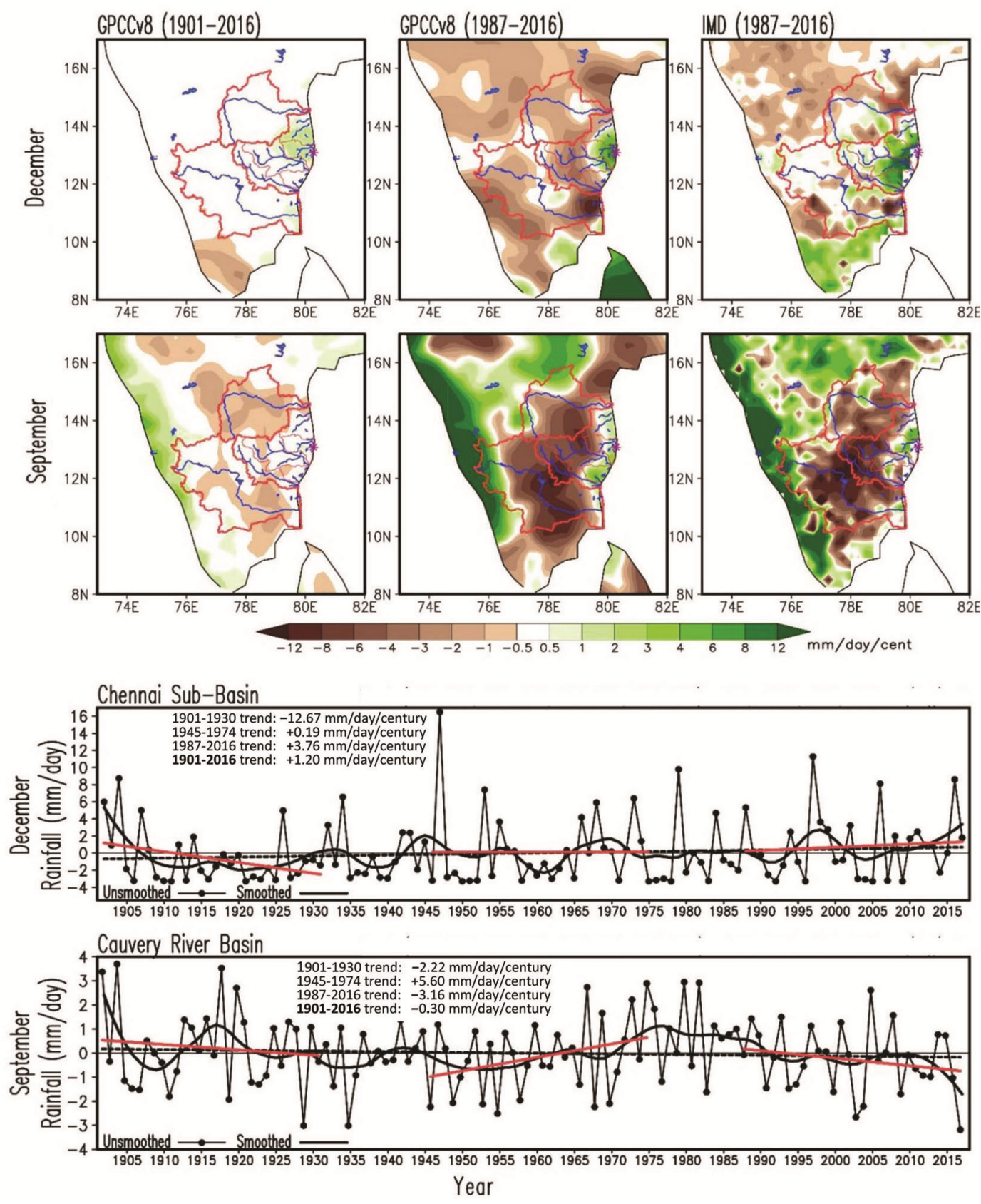

Figure 5. Rainfall trends over Southern Peninsular India. Linear trends are shown in December (first row) (top) and September (second row); recent trends - most positive in the Chennai Sub-basin in December and most negative in the Cauvery basin in September (cf. Figure 4) - motivate the month choice. Trends are shown over 1901-2016 (left) and 1987-2016 (middle, right), the latter from both GPCCv8 and IMDv4 data; all in units of $\mathrm{mm} /$ day/century following the brown-green shading scale. Basinaveraged rainfall anomalies (i.e. departures from normal) during 1901-2016 are plotted for the Chennai Sub-basin in December (third row) and the Cauvery basin in September (last row). The thick black curve shows smoothed rainfall anomalies (from LOESS- $15 \%$ filtering of the 116-yr yearly record) in the lower panels. Both long-period (black dashed line) and short-period (thin red line) rainfall trends in the unsmoothed record are marked and noted.

more than a $10 \%$ reduction in July rainfall in the 20 th century. January is also a challenging month for this basin from the superposition of a significant negative trend on weak climatological rainfall. The recent period trends are again larger and more volatile, e.g. September's large negative trend vis-à-vis modest trend in the adjacent months.

\section{Spatiotemporal distribution of rainfall trends}

The centennial trends are positive over the Chennai (and Naidupet) Sub-basin in December but nondescript in September (Figure 5, left column). In neighbouring basins, trends are nondescript in December but modestly negative in September, especially in central Penner and eastern 
Cauvery basins. The recent period trends (middle-right columns) are far more extensive and impressive: They are positive over the Chennai Sub-basin and stronger in December than September. The December trends are more fractured along the coast, with Chennai in the bull's eye of regional wet trends. The surrounding sea of browns indicates significant rainfall decline over the Cauvery and Penner, and Ponnaiyar and Palar basins in recent decades, especially in September when the GPCC and IMD trends are in good agreement. It is intriguing why the Chennai Sub-basin and its coastal vicinity are carved out region of increasing rainfall in both century-long and recent multidecadal periods, especially the latter, when this region is surrounded by steeply declining rainfall trends.

A more granular temporal view of rainfall variability is shown in the plots of basin-averaged rainfall over 19012016 in Figure 5 (lower panels). Departures from normal (the 116-yr monthly average) are plotted for the Chennai Sub-basin in December (a wet trend month) and Cauvery basin in September (a drying trend month). The former shows large positive departures, more frequent in the latter half of the record. The 2015 December rainfall departure, while notably positive, is not as historic as the 2015 Chennai deluge, as it is exceeded by three previous December months $(1946,1996,1978)$ and nearly equalled by two others $(1903,2005)$; indicating that the days-toweeks long intense rainfall episodes are not always reflected in monthly departures. No less interesting are the multiyear (3-5) periods of strongly deficient December rainfall, e.g. 1920-1924, 1947-1951, 1974-1977 and 2002-2004, when negative rainfall anomalies approach the climatological value $(\sim 3.3 \mathrm{~mm} /$ day $)$, reflecting little/ no rainfall in these periods. Unlike large positive departures that appear sporadic, the large negative ones exhibit multiyear coherence.

\section{Multidecadal variability of rainfall: Atlantic Multidecadal Oscillation and the climate change signal}

Figure 5 (lower panels) highlights the modulation of rainfall on longer timescales; the smooth black curve captures both the multidecadal decline in early 20 th century and the increasing trend in early 21 st century in December rainfall in the Chennai Sub-basin. The 116-yr trend (sloped dashed black line) is $+1.20 \mathrm{~mm} /$ day/century; the recent $30-y r$ trend (red line) is also positive but larger $(+3.76 \mathrm{~mm} /$ day/century); both consistent with trends in Figure 4. Rainfall trends in two non-overlapping 30-yr sub-records, 1901-1930 (early century) and 1945-1974 (mid-century), are strongly negative $(-12.67 \mathrm{~mm} /$ day/ century) and near zero $(+0.19 \mathrm{~mm} /$ day/century $)$ respectively, showing that December rainfall in the Chennai Sub-basin has not risen monotonically, as may be suggested by its centennial or recent period trends. The rainfall record instead consists of multidecadal periods of varying trends, including opposite signed ones.

The Cauvery basin rainfall in September (when recent period trends are most negative, Figure 4) also exhibits significant multidecadal variability against the backdrop of a weakly negative centennial trend $(-0.30 \mathrm{~mm} /$ day/ century; dashed black line). The recent period trend is strongly negative, but it follows a mid-century period (1945-1974) of strongly positive trend $(+5.60 \mathrm{~mm} / \mathrm{day} /$ century), which, in turn, follows an early-century period of negative trend $(-2.22 \mathrm{~mm} /$ day/century $)$. In short, multidecadal trends of alternate sign underlie the weakly negative centennial trend.

\section{Influence of Atlantic Multidecadal Oscillation}

AMO was tracked using the NOAA-AMO index (blue line in Figure 6). Its recent variations include cooling of the North Atlantic basin since the 1950s and its warming since the mid-1970s. The AMO's influence on Peninsular rainfall is apparent from Figure 6 (right panels). The December rainfall regressions, consisting of positive anomalies over the Chennai and Naidupet basins and negative ones elsewhere, including the Cauvery delta, broadly resemble the recent period trends in GPCC rainfall (Figure 5, top-middle). Likewise, regressions of September rainfall on the AMO index, comprising of large deficits over Penner and Cauvery basins, closely resemble the recent period September trends (Figure 5, second row). These resemblances indicate that the influence of AMO on Peninsular rainfall is significant and likely dominant in recent-period trends. The 116-yr correlation of the smoothed AMO index with December rainfall in the Chennai Sub-basin $(+0.23)$ and September rainfall in the Cauvery basin $(-0.59)$ support this assessment.

\section{Climate change signal}

The 116-yr-long rainfall record is clearly not sufficient to encompass multiple cycles of the AMO and as such, the trend in this century-plus period - referred to as centennial trend here - will include some aliasing of multidecadal variability, compromising the integrity of centennial trend as a marker of climate change. A more refined estimate of the climate change signal in rainfall is developed by removing the AMO influence from the rainfall record. The influence is removed by subtracting the product of AMO index (blue curve, Figure 6) and related rainfall regressions (right panel, Figure 6) from the smoothed rainfall record (thick black curve, Figure 6); the AMOremoved rainfall record is shown in Figure 6 by the thin black curve. The 116-yr trend in the AMO-removed December rainfall in the Chennai Sub-basin is $+0.80 \mathrm{~mm} /$ day/century versus $+1.20 \mathrm{~mm} /$ day/century when the 


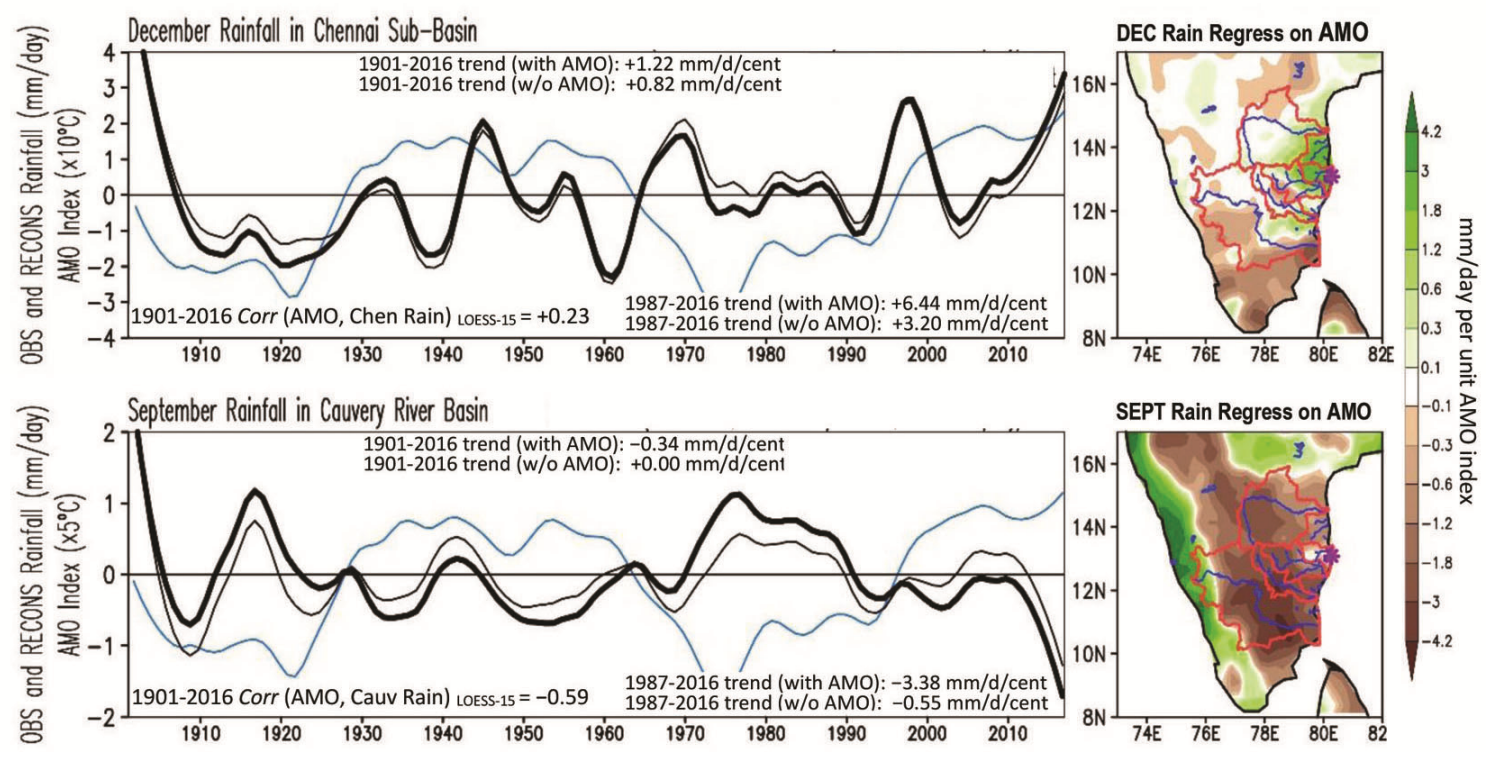

Figure 6. Influence of Atlantic Multidecadal Oscillation (AMO) on Peninsular rainfall. AMO index (LOESS-15\% filtered) is shown in blue in the left panels. Note: Ten times (five times) the index is plotted in the upper (lower) panels. December (September) rainfall regressions on the AMO index are in the upper (lower) right, with brown/green shading indicating negative/positive anomalies, in units of mm/day per unit AMO index. The LOESS-15\% filtered December rainfall anomalies over Chennai Sub-basin are replotted (shown in Figure 5 as well) in the upper left panel using thick black line, and the same anomalies without AMO influence are shown by thin black line. Likewise, for September rainfall anomalies in Cauvery basin in bottom left panel. Long-period (1901-2016) and short-period (1987-2016) trends in basinaveraged rainfall are noted both with and without (w/o) the influence of AMO, in units of mm/day/century (mm/d/cent).

AMO influence is retained. The aliasing of AMO influence thus leads to significant overestimation of the climate change signal in this period. The exclusion of AMO influence flips the trend sign in September rainfall in the Cauvery basin, from -0.30 to $+0.04 \mathrm{~mm} /$ day/century. Although AMO-removed trends can be further adjusted for potential aliasing of other multidecadal variabilities, this analysis strongly cautions against viewing centurylong trends, let alone multidecadal ones, in observed data as markers of the climate change signal.

The AMO influence is even more impressive on shorter-period trends: December rainfall in the Chennai Subbasin and September rainfall in the Cauvery basin exhibit steep trends during 1987-2016: +6.44 and $-3.38 \mathrm{~mm} /$ day/century respectively (Figure 6). Sans AMO influence, the same trends are +3.20 and $-0.55 \mathrm{~mm} /$ day/ century respectively, i.e. smaller by a factor of 2-6; illustrating the fallacy of cavalier attributions of recent multidecadal trends to climate change.

\section{Runoff analysis}

\section{Runoff in the Chennai Sub-basin: climatology and trends}

The rainwater received is not all available for human needs. A significant portion is lost to soil moisture recharge (especially after dry periods), evapotranspiration (water- or energy-limited), infiltration (landscape-dependent, but leading potentially to groundwater recharge) and runoff, which can be harnessed for immediate or later use through storage.

The seasonal cycle of basin-averaged rainfall and runoff in the Chennai Sub-basin shows the May-onward increase of rainfall to mark the end of the dry period (January-May), but runoff remains minimal $(\sim 0.1 \mathrm{~mm} /$ day) until September (Figure 7). The modest JuneAugust rainfall ( $\sim 3 \mathrm{~mm} /$ day) is evidently insufficient for generating runoff, principally because of soil moisture capacitance. Runoff-the rainwater leftover after soil moisture recharge (and evapotranspiration)-is thus lagged vis-à-vis rainfall, but only during build-up of the rainy season. In the exit phase (December-February), runoff variations are near synchronous with rainfall, reflecting at-capacity soil moisture.

The runoff-to-rainfall ratio peaks in February (0.41), i.e. after winter monsoon rainfall when the soil moisture is at capacity. In the recent period (Figure 7, dashed red line), it has peaked earlier - in January - at 0.43 $(=0.28 / 0.65)$, i.e. at a marginally higher value; the January ratio in the 113 -yr climatology is $0.34(=0.28 / 0.82)$, for reference. The higher runoff-to-rainfall ratio in recent January months is potentially interesting. It can arise from a more saturated soil state resulting from higher rainfall in the preceding three months in recent decades (Figure 4, top) and/or from the land-use land-cover change in recent decades that generates more runoff from the same 


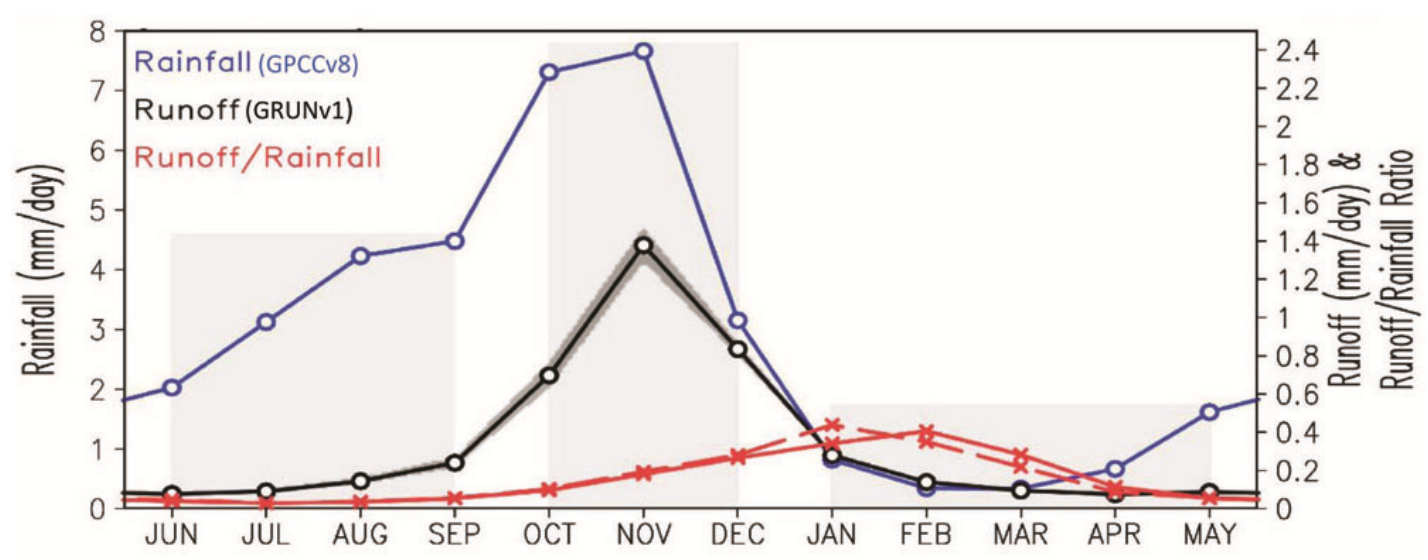

Figure 7. Seasonal cycle of runoff and rainfall in Chennai Sub-basin. Monthly climatology of runoff (black) and rainfall (blue) in the common data period (1902-2014). The basin-averaged runoff to basin-averaged rainfall ratio is shown in red. Note the ratio and runoff are shown using the right vertical scale. The standard deviation of 50 ensemble members about the ensemble-mean runoff (black) provides an estimate of runoff uncertainty; \pm 1 SD spread is shown by grey shaded ribbon. Ratio in the recent 30-yr period (1985-2014) is shown by dashed red line.

rainfall, i.e. a higher ratio. More hydrologic analysis and modelling are clearly needed for this attribution.

\section{Surface rainwater in Chennai Sub-basin: limited availability or suboptimal management?}

Approximately $41 \times 10^{6} \mathrm{~m}^{3} /$ day of rainwater is received in the Chennai Sub-basin, on average, during the winter monsoon (Table 1), but not all of it is available for human needs. An estimate of the amount remaining at the surface (surface water) after hydrologic and atmospheric processing of rainwater is provided by runoff - the available surface rainwater. The average runoff in the Chennai Sub-basin during the winter monsoon is $\sim 0.97 \mathrm{~mm} /$ day (Figure 7), generating an 'available' surface rainwater volume of $\sim 6.57 \times 10^{6} \mathrm{~m}^{3} /$ day during October-December. Not all runoff can be diverted into reservoirs and lakes, nor should it be, as untamed runoff is vital for habitat and ecosystem functioning. The management of surface water is, in any case, not optimal. The estimation uncertainty and harnessing inefficiency notwithstanding, winter monsoon runoff is a pertinent water metric as harnessing regional runoff is the foremost goal of water resource management. In this context, it is both insightful and motivating to express the water stores/resources of the Chennai Sub-basin and the Chennai city's water recruitment, demand and current supply in units of winter monsoon basin-runoff days, even if only a fraction of the basin runoff is being (can be) tapped for consumptive needs. This is motivating because it brings an immediate awareness of the possibilities.

Table 2 takes a step in this direction. For example, the December and January average-fill of the four rainfed reservoirs supplying water to Chennai is $\sim 175 \times 10^{6} \mathrm{~m}^{3}$ or $\sim 27$ basin-runoff days $\left[=175 \times 10^{6} /\left(6.57 \times 10^{6}\right)\right]$ (ref. 10). That is, assuming full harnessing of winter monsoon runoff in the Chennai Sub-basin $\left(6773 \mathrm{~km}^{2}\right)$ and ignoring direct rain-feed and consumptive withdrawals, it would take $\sim 27$ days during winter monsoon to fill these reservoirs from an empty state to their average-fill state. In practice, it would take longer because of the suboptimal harnessing and management of surface water, and because of consumptive drawdowns. Even a three times longer estimate ( $\sim 81$ days) allows attainment of the average-fill state within the 90 day-long winter monsoon period.

Table 2 shows that if all of the winter monsoon runoff in the Chennai Sub-basin is harnessed and stored, it would equal $604 \times 10^{6} \mathrm{~m}^{3} \quad(=92$ days $\times 6.57 \times$ $10^{6} \mathrm{~m}^{3} /$ day), or $\sim 3.45$ times the average-fill of the four reservoirs. Clearly, not all winter runoff in the Chennai Sub-basin can be (should be) harnessed or stored. This cursory analysis, however, suggests that there is potential here - to harness more and store more. Can more runoff be harnessed without disrupting ecosystems and habitats? While this question is beyond the purview of the present analysis, the question on the amount of water storage that would make Chennai resilient against monsoon-related water supply disruptions is tractable.

Lessons from the 2019 Chennai Water Crisis suggest that having seven months of the city's water demand reservoired in January can help cope with monsoon disruptions, excluding multi-year ones. The seven month storage will cover both the January-May dry period and about half of the summer monsoon period (to cover disruptions from delayed onsets). At current demand level (1,200 MLD), seven month of demand equals $\sim 255 \times$ $10^{6} \mathrm{~m}^{3}$, which is only about $\sim 80 \%$ of the full capacity of the four reservoirs $(=11,257$ million cubic feet, or $319 \times$ $10^{6} \mathrm{~m}^{3}$ ) (ref. 10).

Chennai's seven month demand can thus be met by harvesting $\sim 42 \%(=255 / 604)$ of winter monsoon runoff 
Table 2. Water in the Chennai Sub-basin: Basin-integrated winter monsoon rainwater and runoff are compared with other water resources. Runoff is the rainwater leftover after hydrologic and atmospheric processing of rainfall. As harnessing runoff is an important goal of water resource management, the water stores/resources of the region are expressed in units of basin-runoff days

Water in the Chennai Sub-basin during winter

Chennai Sub-basin area: $6,773 \mathrm{~km}^{2}$; Chennai metro area: $173 \mathrm{~km}^{2}$

Equivalent basin-runoff days

Runoff Volume (sub-basin integrated)

GRUNv1, 1901-2014; October-December climatology

Rainwater Volume (sub-basin integrated; Table 1)

GPCCv8, 1901-2016; October-December climatology

Average-fill of Chennai's four reservoirs

Poondi, Cholavaram, Redhills, and Chembarambakkam

2005-2019, December-January average ${ }^{1}$

Krishna Water ${ }^{2}$

Permitted uptake (via Telugu Ganga Canal)

2019 Receipt

2020 Receipt $^{3}$

Cauvery Water ${ }^{4}$

From Mettur Dam via Veeranam Lake

April 2019 delivery (piped)

Desalination Yield ${ }^{5}$

From Minjur and Nemmeli plants

Chennai City Water Demand ${ }^{6}$

Median estimate:1200 million litres/day (MLD)

Chennai City Water Supply ${ }^{7}$

Peak supply estimate: 850 MLD

Rainwater Harvesting ${ }^{8}$

2017 estimate (339 million cubic feet)

$\begin{array}{lc}6.57 \times 10^{6} \mathrm{~m}^{3} / \text { day } & 1 \\ 41.18 \times 10^{6} \mathrm{~m}^{3} / \text { day } & \sim 6 \\ & \\ \sim 175 \times 10^{6} \mathrm{~m}^{3} & \sim 27 \\ \sim 425 \times 10^{6} \mathrm{~m}^{3} & \sim 65 \\ \sim 45 \times 10^{6} \mathrm{~m}^{3} & \sim 7 \\ \sim 166 \times 10^{6} \mathrm{~m}^{3} & \sim 25 \\ & \\ \sim 0.17 \times 10^{6} \mathrm{~m}^{3} / \text { day } & \sim 0.03 \\ \sim 0.2 \times 10^{6} \mathrm{~m}^{3} / \text { day } & \sim 0.03 \\ \sim 1.20 \times 10^{6} \mathrm{~m}^{3} / \text { day } & \sim 0.18 \\ \sim 0.85 \times 10^{6} \mathrm{~m}^{3} / \text { day } & \sim 0.13 \\ 9.6 \times 10^{6} \mathrm{~m}^{3} & \sim 1.46\end{array}$

${ }^{1}$ Computed from data at Chennai Metropolitan Water Supply and Sewage Board (CMWSSB); http://123.63.203.150/public/lake.htm

${ }^{2}$ The Indian Express, 10 January 2019 (ref. 14).

${ }^{3} 5850$ million cubic feet (mcft) of Krishna water released. The Times of India, 22 February 2020; https://timesofindia.indiatimes.com/ city/chennai/with-5-85-tmcft-of-krishna-water-realised-so-far-chennais-water-supply-can-last-6-months/articleshow/74251398.cms

${ }^{4}$ The Times of India, 20 April 2019 (ref. 15).

${ }^{5}$ Minjur and Nemmeli salination plants; CMWSSB (ref. 16).

${ }^{6}$ Chennai's water demand estimates vary by a factor of 2: From $\sim 0.5 \mathrm{mcft} /$ day (or $0.14 \times 10^{6} \mathrm{~m}^{3} /$ day) by The Times of India (20 April 2019; ref. 15) to $\sim 1200$ MLD by CMWSSB, and 1,300 MLD by others (https://www.futuredirections.org.au/publication/india-chennai-confronts-another-watercrisis/).

${ }^{7}$ FutureDirections.org.au (26 June 2019; https://www.futuredirections.org.au/publication/india-chennai-confronts-another-water-crisis/).

${ }^{8}$ Water Management in Chennai; https://en.wikipedia.org/wiki/Water_management_in_Chennai\#cite_note-TH_VanishingWaterbodies-2

in the Chennai Sub-basin. To offset reservoir losses (especially evaporative), more would need to be harvested and stored: while existing reservoir capacity will permit additional storage, can more (or even $42 \%$ ) runoff be harvested? Chennai's water woes certainly do not stem from limited water warehousing capacity.

\section{Concluding remarks}

Southeastern India experienced acute water shortages during the summer of 2019, headlined by the Chennai Water Crisis. Just four years prior, the same region was in the news for the late November-early December deluge that led to significant loss of life and property. As this section of the Coromandel Coast, which receives $\sim 50 \%$ of annual rainfall in winter, reels from the impact of extreme rainfall swings, questions on the origin of these extremes have arisen, in particular, on the anthropogenic contribution from rising global concentration of greenhouse gases as well as regional land-use land-cover change.

Analysis of the 1901-2016 rainfall record in the Chennai Sub-basin - an $\sim 6700 \mathrm{~km}^{2}$ region that surrounds and includes the $\sim 173 \mathrm{~km}^{2}$ Chennai Metro Area-shows insignificant (but positive) trends in monsoon rainfall, except in June and December when the trends (still positive) are notable. Natural climate variability, exemplified by Atlantic Multidecadal Oscillation, contributes to these trends, especially multidecadal ones, cautioning against cavalier attributions of recent-period trends and the Chennai Water Crisis to climate change.

Runoff - the rainwater leftover after its hydrologic and atmospheric processing - can be harnessed for immediate or later use through storage. Analysis of objectively obtained and observationally constrained (by river basin discharge) estimates of runoff in the Chennai Sub-basin shows low values during summer monsoon because of modest rainfall and soil-moisture recharge (from the preceding season being dry). The runoff-to-rainfall ratio 
rises steadily during winter monsoon, from $\sim 0.1$ to $\sim 0.3$.

A novel water metric is introduced to increase awareness of the runoff harvesting potential: Water stores/ resources in the Chennai Sub-basin and Chennai city's water recruitment, demand and supply are expressed in units of winter monsoon basin-runoff days, even if only a fraction of the basin runoff is being (can be) harvested for consumptive needs. For example, Chennai's daily water demand is equivalent to $\sim 0.18$ days of winter monsoon runoff in the Chennai Sub-basin, while the city's four reservoirs can be filled to their December and January average-fill level using $\sim 27$ days of the Chennai Sub-basin's runoff.

It is shown that harnessing and storing $\sim 42 \%$ of winter monsoon runoff in the Chennai Sub-basin can fulfil about seven months (January-July) of Chennai city's water demand, covering the dry period (January-May) and buffering the impact of delayed monsoon onsets (June and July). It is furthermore shown that storing this runoff will not require new warehousing facilities as the four reservoirs currently supplying water to Chennai city can store $\sim 42 \%$ of the winter runoff at just $80 \%$-full capacity.

Can $42 \%$ of the winter runoff in the Chennai Sub-basin be harvested? Answering this question is difficult, but working backwards from the reservoirs' average-fill state $\left(175 \times 10^{6} \mathrm{~m}^{3}\right)$ yields $\sim 29 \%$ harvesting fraction, assuming reservoirs are fed by winter runoff but not direct rainfall. Even if this is an overestimate, harvesting $42 \%$ of the winter runoff no longer seems beyond the realm of possibilities.

In short, Chennai city's water woes arise not from insufficient rainwater in the regional sub-basin, but suboptimal harnessing of related runoff. The present analysis supports the notion 'Metro cities in India are rain-rich but water-starved, ${ }^{39}$, or its more nuanced version, 'Metro cities are in runoff-rich regions but water-deprived nonetheless'.

1. Mishra, A. K., Monitoring Tamil Nadu flood of 2015 using satellite remote sensing. Nat. Hazards, 2016, 82, 1431-1434; doi:10.1007/s11069-016-2249-5

2. The Economist, Next time by water. 12 December 2015; https://www.economist.com/asia/2015/12/12/next-time-by-water

3. Narasimhan, B., Bhallamudi, S. M., Mondal, A., Ghosh, S. and Mujumdar, P., Chennai floods 2015: a rapid assessment. Interdisciplinary Centre for Water Research, Indian Institute of Science, Bengaluru, 2016.

4. Patel, K., Water Shortages in India, NASA's Earth Observatory, 19 June 2019; https://earthobservatory.nasa.gov/images/145242/ water-shortages-in-india

5. Sreekala, P. P., Vijaya Bhaskara Rao, S., Rajeevan, K. and Arunachalam, P. P., Combined effect of MJO, ENSO and IOD on the intraseasonal variability of northeast monsoon rainfall over south peninsular India. Climate Dyn., 2018; https://doi.org/10.1007/ s00382-018-4117-3.
6. Krishnamurthy, L. et al., Causes and probability of occurrence of extreme precipitation events like Chennai 2015. J. Climate, 2018, 31(10), 3831-3848; see figure 1.

7. Sengupta, A. and Nigam, S., The northeast winter monsoon over the Indian subcontinent and Southeast Asia: evolution, interannual variability, and model simulations. J. Climate, 2019, 32, 231-249; see figures 2 and 3.

8. Sengupta, A., Sea surface temperature-based statistical prediction of South Asian summer monsoon rainfall distribution, Ph.D. thesis, University of Maryland Graduate School, College Park, USA, 2019, p. 164; see figure 3.2.

9. Kumar-Rao, A., India's water crisis could be helped by better building, planning. National Geographic, 15 July 2019; https://www.nationalgeographic.com/environment/2019/07/indiawater-crisis-drought-could-be-helped-better-building-planning/

10. Chennai Metropolitan Water Supply and Sewage Board; http://123.63.203.150/public/lake.htm

11. Sikka, D. R., Some aspects of the large scale fluctuations of summer monsoon rainfall over India in relation to fluctuations in the planetary and regional scale circulation parameters. Proc. Indian Acad. Sci. Earth Planet Sci., 1980, 89, 179-195.

12. Rasmusson, E. M. and Carpenter, T. H., The relationship between eastern equatorial Pacific sea surface temperatures and rainfall over India and Sri Lanka. Mon. Weather Rev., 1983, 111, $517-528$.

13. Nikku, B. R., Water rights, conflicts and collective action: case of Telugu Ganga Project, India. Presentation at the Tenth Biennial Conference of the International Association for the Study of Common Property, Mexico, 2005; http://dlc.dlib.indiana. edu/dlc/bitstream/handle/10535/1094/Nikku_Water_040513_Paper088.pdf

14. The New Indian Express, 10 January 2019; https://www. newindianexpress.com/states/andhra-pradesh/2019/jan/10/chennaimay-not-get-full-quota-of-krishna-water-from-ap-in-2019-1923178. html

15. The Times of India, Chennai City Edition, 20 April 2019; https://timesofindia.indiatimes.com/city/chennai/veeranam-laketurns-a-major-water-supplier-for-the-city/articleshow/68960792.cms

16. Minjur (https://chennaimetrowater.tn.gov.in/desalination.html) and Nemmeli (https://chennaimetrowater.tn.gov.in/desalination-Nemmeli. html)

17. Gopalakrishnan, S., Water warriors of Chennai. India Water Portal, 19 March 2014; https://www.indiawaterportal.org/articles/waterwarriors-chennai-ragade-and-raghavan

18. Jayaraman, N., Viewpoint: Why India's Chennai has run out of water. BBC, 2 July 2019; https://www.bbc.com/news/world-asiaindia-48797399

19. Frayer, L., The water crisis in Chennai, India: who's to blame and how do you fix it? National Public Radio, 18 July 2019; https://www.npr.org/sections/goatsandsoda/2019/07/18/742688141/ the-water-crisis-in-chennai-whos-to-blame-how-do-you-fix-it

20. Amante, C. and Eakins, B. W., ETOPO1 1 arc-minute Global Relief Model: procedures, data sources, and analysis. NOAA Technical. Memo NESDIS NGDC-24, 2009, p. 25.

21. BfG, Major river basins of the world, Global runoff data Centre, Federal Institute of Hydrology, Germany, 2007.

22. FAO, AQUAMAPS Global Spatial Database on Water and Agriculture: rivers/water bodies. Food and Agriculture Organization, Rome, Italy.

23. Lehner, B., Hydro HydroSHEDS, Technical documentation, version 1.2. Conservation Science Program, World Wild Life Fund, USA, 2013, p. 25.

24. Wang, Y. Q., MeteoInfo: GIS software for meteorological data visualization and analysis. Meteorol. Appl., 2016, 21, 360-368; https://doi.org/10.1002/met.1345.

25. Grid Analysis and Display System (GrADS), COLA, George Mason University, Fairfax, VA; http://cola.gmu.edu/grads/ 
26. Schneider, U., Becker, A., Finger, P., Meyer-Christoffer, A. and Ziese, M., GPCC Full Data Monthly Product Version 2018 at $0.25^{\circ}$ : Monthly land-surface precipitation from rain gauges built on GTS-based and historical data; doi:10.5676/DWD_GPCC/ FD_M_V2018_025.

27. Pai, D. S., Sridhar, L., Rajeevan, M., Sreejith, O. P., Satbhai, N. S. and Mukhopadhyay, B., Development of a new high spatial resolution $\left(0.25^{\circ} \times 0.25^{\circ}\right)$ Long period $(1901-2010)$ daily gridded rainfall data set over India and its comparison with existing data sets over the region. Mausam, 2014, 65(1), 1-18.

28. Ghiggi, G., Humphrey, V., Seneviratne, S. I. and Gudmundsson, L., GRUN: An observations-based global gridded runoff dataset from 1902 to 2014. Earth Syst. Sci. Data Discuss, 2019, doi:https://doi.org/10.5194/essd-2019-32

29. Zhang, R. and Delworth, T. L., Impact of Atlantic multidecadal oscillations on India/Sahel rainfall and Atlantic hurricanes. Geophys. Res. Lett., 2006, 33, L17712.

30. Krishnamurthy, L. and Krishnamurthy, V., Decadal scale oscillations and trend in the Indian monsoon rainfall. Climate Dyn., 2014, 43, 319-331.

31. Nigam, S., Zhao, Y., Ruiz-Barradas, A. and Zhou, T., The southflood north-drought pattern over Eastern China and the drying of the Gangetic Plain: observations, simulations, and origin. In Climate Change: Multidecadal and Beyond (eds Ghil, M. et al.), World Press, 2016, p. 376.

32. Enfield, D. B., Mestas-Nuñez, A. M. and Trimble, P. J., The Atlantic multidecadal oscillation and its relation to rainfall and river flows in the continental US. Geophys. Res. Lett., 2001, 28, 2077-2080; https://doi.org/10.1029/2000GL012745.

33. Cleveland, W. S. and Loader, C. L., Smoothing by local regression: principles and methods. In Statistical Theory and Computational Aspects of Smoothing (eds Haerdle, W. and Schimek, M. G.), Springer, 1996, pp. 10-49; doi https://doi.org/10.1007/978-3642-48425-4_2
34. Nigam, S., Guan, B. and Ruiz-Barradas, A., Key role of the Atlantic multidecadal oscillation in 20th-century drought and wet periods over the Great Plains. Geophys. Res. Lett., 2011, 38, L16713, https://doi.org/10.1029/2011GL048650.

35. Kavvada, A., Ruiz-Barradas, A. and Nigam, S., AMO's structure and climate footprint in observations and IPCC AR5 climate simulations. Climate Dyn., 2013, doi:10.1007/s00382-013-1712-1.

36. Nigam, S., Sengupta, A. and Ruiz-Barradas, A., Atlantic-Pacific links in observed multidecadal SST variability: is Atlantic multidecadal oscillation's phase-reversal orchestrated by Pacific decadal oscillation? J. Climate, 2020, 33, 5479-5505.

37. Nigam, S. and Ruiz-Barradas, A., Seasonal hydroclimate variability over North America in Global and Regional Reanalyses and AMIP simulations: varied representation. J. Climate, 2006, 19, 815-837.

38. Trenberth, K. E. and Jones, P. D., Climate Change 2007: The Physical Science Basis (eds Solomon, S. et al.), Cambridge University Press, 2007, pp. 235-336.

39. Raghavan, S., Rainwater Harvesting - The Success Story of Chennai, 2018; http://site.iee.org/indiacouncil/files/2018/08/p30p34.pdf

ACKNOWLEDGEMENTS. We acknowledge the support of the Ministry of Earth Sciences, Government of India, through a Monsoon Mission grant. Sumant Nigam was also supported by the Fulbright-Nehru Fellowship from the Fulbright Foundation, US-India Educational Foundation (USIEF), and the Indian Institute of Technology, Mandi.

Received 26 June 2020; revised accepted 19 October 2020

doi: $10.18520 / \mathrm{cs} / \mathrm{v} 120 / \mathrm{i} 1 / 43-55$ 